\title{
A Fungal Parasite Regulates a Putative Female-Suppressor Gene Homologous to Maize Tasselseed2 and Causes Induced Hermaphroditism in Male Buffalograss
}

\author{
Ambika Chandra and David R. Huff \\ Department of Crop and Soil Sciences, 116 Agricultural Sciences and Industries Building, The Pennsylvania State University, \\ University Park, PA 16802, U.S.A.
}

Submitted 23 July 2009. Accepted 3 November 2009.

\begin{abstract}
Parasitically induced hermaphroditism is a fascinating illustration of floral sex organ modification; however, knowledge of how parasites induce hermaphroditism in plants is limited. Here, we show the fungal parasite pistil smut induces development of female sex organs (pistils) in flowers of male buffalograss, potentially by downregulating a putative female-suppressor gene, $B d T s 2$, homologous to maize Tasselseed2 (ZmTs2). Full-length BdTs2, isolated using rapid amplification of cDNA ends, exhibits $89 \%$ nucleotide sequence similarity with $Z m T s 2$ and $85 \%$ amino acid sequence homology with $Z m T s 2$ protein. Scanning electron micrographs demonstrate that unisexual buffalograss flowers develop through a process of selective abortion of opposite sex organs within hermaphroditic floral primordia. Quantitative real-time polymerase chain reaction showed that high expression levels of $B d T s 2$ within male inflorescences correlate with the selective abortion of gynoecium, leading to the development of unisexual male flowers. RNA in situ hybridization confirmed the expression of BdTs2 precisely within vestigial gynoeciums of male flowers and not in other floral organs of the inflorescence. Furthermore, we show that $B d T s 2$ expression is downregulated by pistil smut infection, which corresponds to the presence of pistils in flowers otherwise destined to become unisexual male. This study provides a potential molecular basis for pistil smut-induced hermaphroditism in male buffalograss.
\end{abstract}

The destruction or alteration, or both, of sexual reproductive organs in plants by fungal parasites belongs to a class of disease known as parasitic castration (Clay 1991; Fischer and Holton 1957). Parasitically induced destruction of host sexual reproductive organs is illustrated by Epichlö fungal endophytes preventing the development of inflorescences of their perennial grass hosts, causing choke disease (Sampson 1933), and by various smut and bunt fungi destroying the developed

Nucleotide and amino acid sequences for $B d T s 2$ have been deposited in the GenBank database with accession numbers DQ457002 and ABE65370, respectively. Pistil smut-infected buffalograss inflorescences, containing ovaries filled with fungal teliospores (smut balls), are available upon request.

Current address for A. Chandra: Texas AgriLife Research-Dallas, Texas A\&M System, 17360 Coit Road, Dallas, TX 75252, U.S.A.

Corresponding author: D. R. Huff; E-mail: drh15@psu.edu; Telephone: +1-814-863-9805; Fax: +1-814-863-7043. inflorescences of their hermaphroditic hosts by parasitizing sex organs within the flowers (Duran and Fischer 1961). An interesting demonstration of parasitically induced alteration of host sexual reproductive organs is the phenomenon known as induced hermaphroditism, wherein a parasite induces opposite sex organs in individuals that would otherwise bear only a single sex (Fisher and Holton 1957). Sex organs within these induced hermaphroditic phenotypes are parasitized and, hence, reproductively sterile. However, the development of these parasitically induced organs appears so natural that early taxonomists were provoked into misidentifying fungal-induced hermaphroditic phenotypes of dioecious species as new hermaphroditic varieties (Fischer and Holton 1957; Hood and Antonovics 2003).

The best-known example of parasitically induced hermaphroditism in plants is caused by the anther smut fungus [Microbotryum violaceum (Pers.) G. Deml \& Oberw. (syn. Ustilago violacea (Pers.) Fuckel), a member within the division Basidiomycota] in female plants of dioecious campion species (Silene spp. belonging to the family Caryophyllaceae). Anther smut induces the development of male sex organs in otherwise female plants but does not alter the sex organ development in male plants of campion (Uchida et al. 2003). Anthers of infected male and female plants contain teliospores instead of pollen, while the ovaries of infected female plants are sporefree but reduced in size and sterile (Uchida et al. 2003; Ye et al. 1991). Sporulation in the anthers of infected flowers facilitates disease transmission by disseminating anther smut spores instead of pollen grains through insect pollinators (Altizer et al. 1997; Young 2002), and as such, the Silene-anther smut system has proven useful as a model system to understand ecological and evolutionary disease dynamics in natural populations (Alexander and Antonovics 1988; Antonovics et al. 2002). The Silene-anther smut system has also proved vital in identifying genes involved in the development of male sex organs (androeciums) of Silene by correlating expression patterns of these genes in unisexual male and female sex forms compared with anther smut-infected females (Ageez et al. 2005; Jenkins et al. 2005; Kazama et al. 2009; Scutt et al. 1997).

A relatively unknown example of parasitically induced hermaphroditism is in sharp contrast to the Silene-anther smut system and is caused by the pistil smut fungus [Salmacisia buchloëana Huff \& Chandra (syn. Tilletia buchloëana Kellerman and Swingle)] in flowers (termed florets in grasses) of dioecious buffalograss [Bouteloua dactyloides Columbus (syn. Buchlö̈ dactyloides (Nutt.) Engelm.)] (Chandra and Huff 
2008). In male plants of buffalograss (Fig. 1A and D), pistil smut infection induces the development of female sex organs (pistils) (Fig. 1E), as is evident by the presence of purple feathery stigmas in male florets (Fig. 1C). In female plants of buffalograss (Fig. 1B and F), pistil smut infection induces vestigial male sex organs (androeciums) to increase in size (Fig. $1 \mathrm{G})$, thus making mature florets of both male and female unisexual plants appear hermaphroditic (Chandra and Huff 2008).
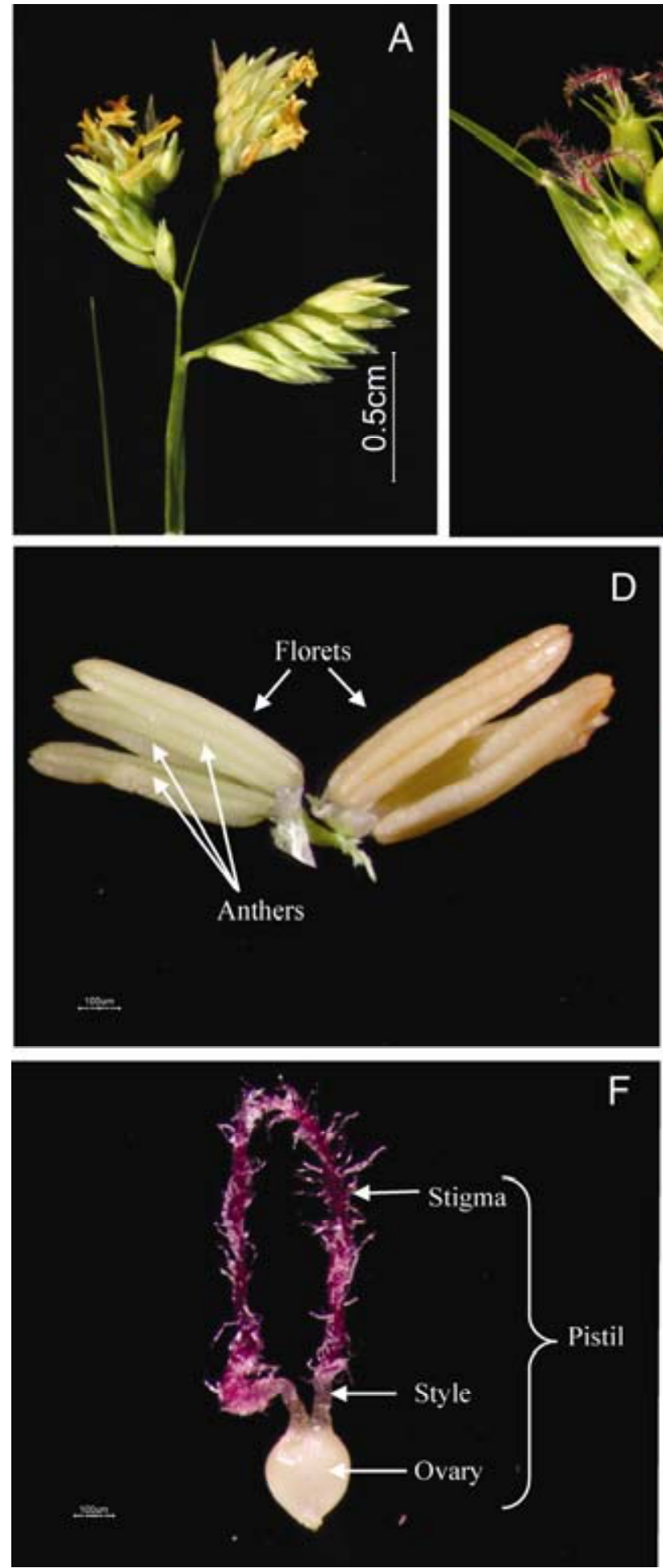
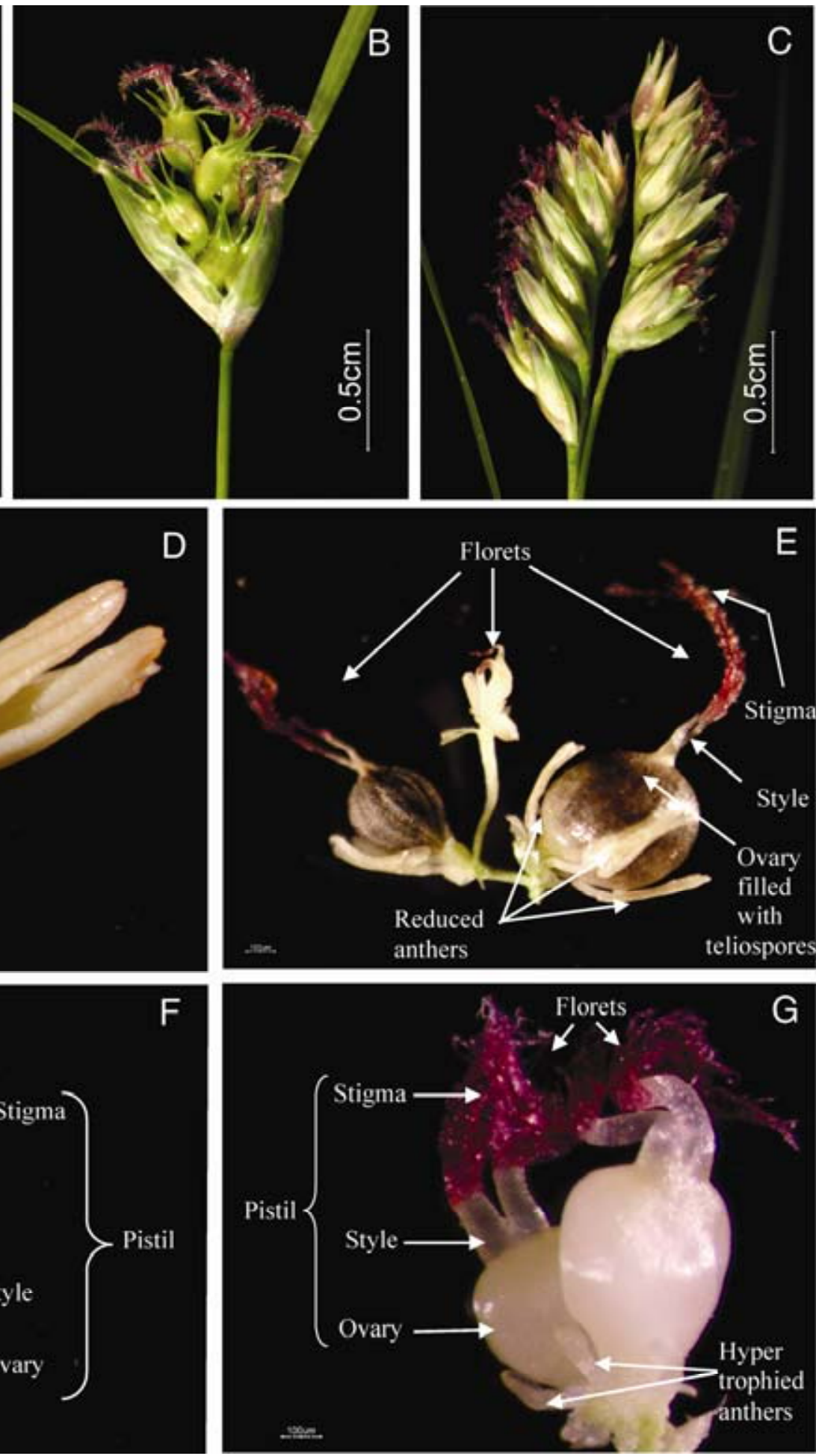

Fig. 1. Comparisons of inflorescence, spikelets, and florets of male and female sex forms of buffalograss noninfected and infected with the pistil smut fungus. A, Inflorescences of noninfected male plants extend above basal meristem leaves and the flag leaf, typically bearing two to three spikes, with functional pollen-producing anthers extended. B, Inflorescences of noninfected female plants are shorter and remain within the foliage of basal meristem leaves and the flag leaf, typically bearing three to four spikes (seed dispersal capsules), with purple feathery stigmas extending from within the florets. C, Inflorescence of infected male plant contains induced female sex organs (pistils), as evidenced by the presence of purple, feathery stigmas. D, Spikelet of noninfected male plant contains two florets, each with three well-developed stamens (anther + filament). E, Spikelet of infected male plant contains three florets, each with three reduced stamens and a fully developed pistil (stigma + style + ovary); ovaries are supplanted with teliospores forming smut balls. F, Spikelet of noninfected female plant contains a single fully developed pistil and three vestigial stamens. G, Spikelet of infected female plant contains two florets, each with a fully developed pistil and three hypertrophied stamens. 
In addition, pistil smut infection presumably affects meristem determinancy and results in the development of an additional floret per spikelet in both male and female inflorescences of buffalograss, i.e., the development of three florets per spikelet in infected male plants (Fig. 1E) as compared with two in noninfected male plants (Fig. 1D) and the development of two florets per spikelet in infected female plants (Fig. 1G) as compared with one in noninfected female plants (Fig. 1F). Pistil ovaries of infected male and female plants are filled with fungal teliospores rendering them reproductively sterile (i.e., parasitically castrated); whereas, the anthers within these induced hermaphroditic florets do not contain teliospores but are underdeveloped in size and, hence, nonfunctional.

Pistil smut is a biotrophic fungus and grows endophytically within buffalograss vegetative meristems (Chandra and Huff 2008). Host infection occurs through penetration of infection hyphae into basal meristems (Fig. 2A) following the dispersal of teliospores formed in parasitized ovaries (Fig. 2C) and through the transmission of mycelium from infected plants to daughter plants during vegetative propagation (Fig. 2B). Despite its interesting biology and agronomic utility of inducing development of potential seed-bearing organs, the molecular or biochemical mechanism underlying pistil smut-induced hermaphroditism has yet to be examined. Here, we show a potential molecular basis for pistil smut-induced hermaphroditism in male buffalograss.

Flowering plants exhibit a wide variety of breeding systems, including some in which sexes are separated onto different individuals (dioecy) or onto different flowers of the same individual (monoecy). Current theoretical models for the evolution of dioecy or monoecy accentuate that these unisexual flowers have evolved, perhaps multiple times, from their hermaphroditic ancestors (Barrett 2002; Charlesworth 2002; Charlesworth and Charlesworth 1978). The evolutionary transition from hermaphroditic precursor to unisexual flowers requires the involvement of many sex-determining genes, including malesuppressor and female-suppressor factors (Westergaard 1958). To date, many sex-determining plant genes have been theorized, but only two putative female-suppressor genes, Tasselseed1 (Ts1) and Tasselseed2 (Ts2) from maize (Zea mays L.), have been cloned, sequenced, and characterized (Acosta et al. 2009; Delong et al. 1993). In monoecious maize, the nonhomeotic mutants $t s 1$ and $t s 2$ allow pistils to complete development in otherwise unisexual male (staminate) florets (Calderon-Urrea and Dellaporta 1999; Irish et al. 1994). Ts2 codes for a short-chain dehydrogenase reductase (SDR) pro-

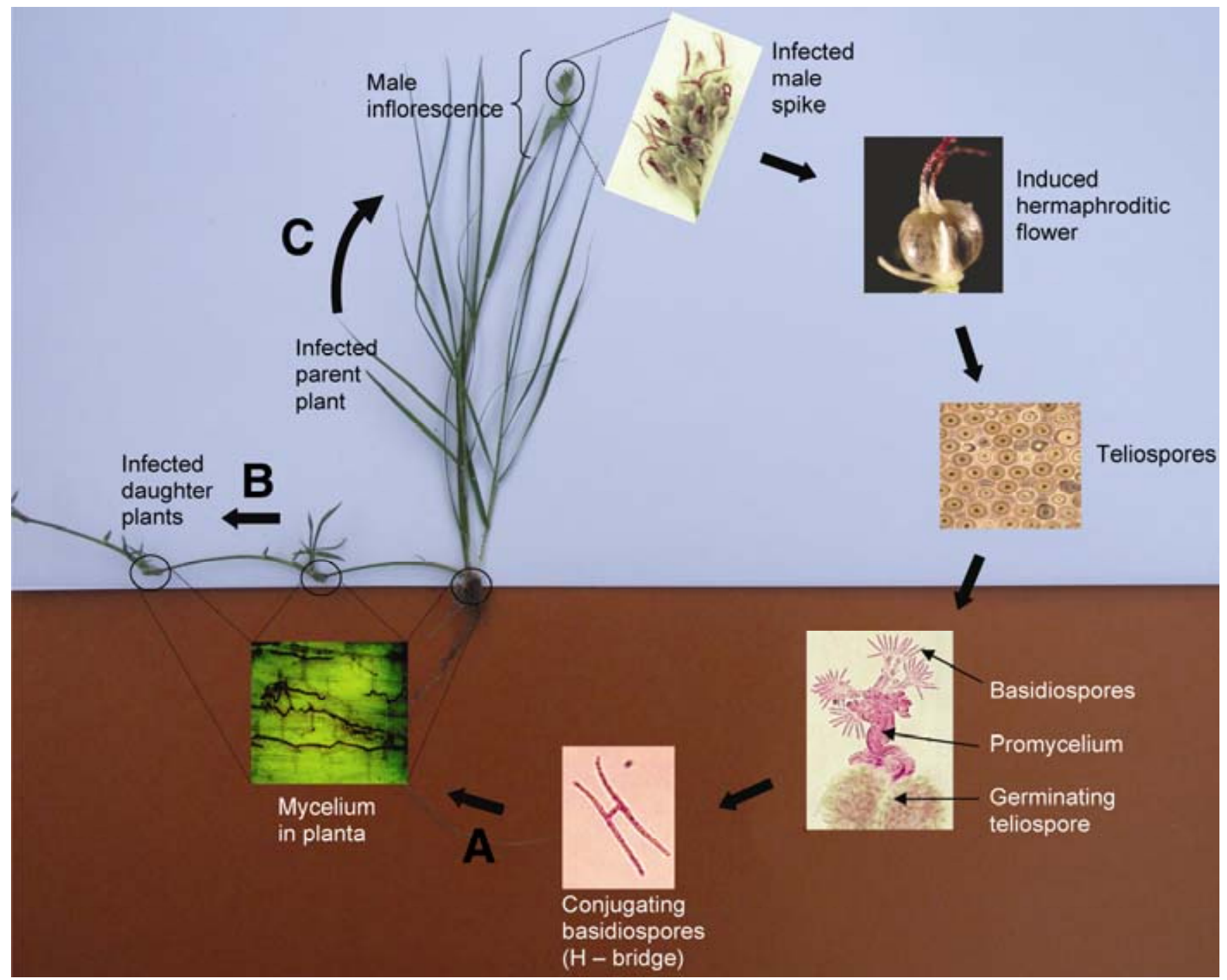

Fig. 2. Life cycle and modes of dissemination of the pistil smut fungus. A, Host infection occurs through specialized infection hyphae. B, Endophytic fungal mycelium is transmitted from infected parent plants to daughter plants during vegetative growth. C, Dispersal of teliospores formed in the ovaries of infected plants spread to healthy plants. Adapted from Chandra and Huff 2008. 
tein and presumably causes pistil abortion through cell-death programming within hermaphroditic floral primordia at the gynoecial ridge stage of development, resulting in staminate florets (Calderon-Urrea and Dellaporta 1999; Delong et al. 1993; Wu et al. 2007). An ortholog of Ts2, Gsf1 (gynomoecious sex form 1), exhibits expression patterns that also correlate with pistil abortion within staminate florets of a wild relative of maize, eastern gamagrass, suggesting a common sex determination mechanism in the grass tribe Andropogoneae (subfamily Panicoideae) (Li et al. 1997). In wild-type maize, Ts1 protein has recently been shown to encode a plastid-targeted lipoxygenase with predicted 13-lipoxygenase specificity, suggesting the role of $T_{s} 1$ in the jasmonic-acid biosynthetic pathway (Acosta et al. 2009).

Buffalograss exhibits an environmentally stable subdioecious sexual reproductive system with approximate 1:1 male to female sex ratios (Huff and Wu 1987, 1992). Pistil smut-induced hermaphroditism of male buffalograss appears to phenotypically mimic maize $t s 1 / t s 2$ and Tripsacum gsfl mutants. For the present study, we have chosen $T s 2$ as a candidate gene to investigate pistil smut-induced hermaphroditism in male buffalograss. As a member of the subfamily Chloridoideae, buffalograss is genetically distant from maize and eastern gamagrass, both of which belong to the subfamily Panicoideae. Subfamilies Chloridoideae and Panicoideae are, however, members of the monophyletic PACCMAD clade (Panicoideae, Arundinoideae, Centothecoideae, Chloridoideae, Micrairoideae, Aristidoideae, Danthonioideae) of the grass family Poaceae (Sanchez-Ken et al. 2007). Despite the great genetic distance separating buffalograss from either maize or eastern gamagrass, our experimental hypothesis was that a $T s 2$-like gene is a key player in the separation of sexes during buffalograss unisexual floret development and that pistil smut either directly or indirectly regulates $T s 2$ activity, thereby inducing hermaphroditism in staminate florets.

\section{RESULTS}

We began our investigation by examining the development of unisexual florets in buffalograss at the microscopic level and found that florets of either male or female sex forms begin development as hermaphrodites, initiating both male (androecium) and female (gynoecium) organ primordia (Fig. 3). As the hermaphroditic primordia reach the gynoecial ridge stage of development, male and female suppressor factors begin a process of selective abortion. Male-suppressor factors result in the selective abortion of male sex organs in florets destined to become female. Similarly, female-suppressor factors result in the selective abortion of female sex organs in florets destined to become male. These developmental constraints laid down by suppressor factors are characterized by the vestigial organ remains of aborted sex organs (Mitchell and Diggle 2005) (Fig. 3). Buffalograss florets acquire their unisexual identity as the unaborted sex organs are allowed to develop and reach full maturity.

Rapid amplification of cDNA ends (RACE) allowed us to amplify, clone, and sequence the full-length cDNA (1,226 nt) homolog of $T s 2, B d T s 2$ (DQ457002) from noninfected male buffalograss. BdTs 2 showed the highest level of amino acid sequence similarity, approximately $94 \%$, with related species within its genus Bouteloua (Kinney et al. 2003) and exhibited $85 \%$ amino acid sequence similarity with maize Ts2 (ZmTs2) protein. SDR proteins display characteristic GxxGxG and YxxxK amino acid motifs among its orthologs (Malcomber and Kellogg 2006). The multiple alignment of the predicted amino acid sequence of $B d T s 2$ with $Z m T s 2$, Gsf1, and $T s 2$ homologs from close relatives of buffalograss (Bouteloua spp.) display shared GARGIG and YTASK amino acid motifs (Fig.
4, yellow-shaded areas). Overall, amino acid sequence alignment shows high consensus, except for a hypervariable region corresponding to amino acid position 246 to 259 of buffalograss (Fig. 4, gray-shaded area), which interestingly, is shared with maize and eastern gamagrass but not with other Bouteloua species.

Quantitative real-time polymerase chain reaction (PCR) was performed to measure the relative expression levels of $B d T s 2$ mRNA over different stages of inflorescence development (Fig. 5). BdTs 2 expression was low during early stages of both male and female inflorescence development. However, BdTs 2 expression reached a considerably higher level (eightfold increase) in male inflorescences compared with female inflorescences shortly after the late-boot stage of inflorescence development. Later stages of male inflorescence development exhibited the highest levels of $B d T s 2$ expression. The high levels of $B d T s 2$ expression in developing male inflorescences were found to correlate with the absence of pistils in male florets, while low levels of BdTs2 expression in developing female inflorescences correlate with the presence of pistils in female florets (Fig. 5). These results suggest a potential role for $B d T s 2$ in the unisexual floret development of male buffalograss. Ts 2 has been shown to express in other plant tissues, such as roots and leaves (Malcomber and Kellogg 2006). In our study, we also observed low levels of $B d T s 2$ expression in leaves and nodes (vegetative meristems) of both infected and noninfected buffalograss (Fig. 5). In order to verify that the high expression level of $B d T s 2$ in male inflorescences was attributed to its expression in arrested pistils and not in other floral organs, we performed RNA in situ hybridization.

RNA in situ hybridization demonstrated that the spatial expression of $B d T s 2$ in immature male florets was precisely localized in subepidermal layers of the vestigial gynoecium whose development had been arrested exactly at the gynoecial ridge stage (Fig. 6). We did not observe BdTs 2 expression in any other floral organs, such as lemmas, paleas, filaments, or anthers (Fig. 6), suggesting that the high expression levels in noninfected male inflorescences were mainly attributable to $B d T s 2$ expression within arrested gynoeciums. This result demonstrated that the spatial and temporal correlation between $B d T s 2$ expression and pistil abortion is analogous to maize and eastern gamagrass and suggests that $B d T s 2$ is presumably one of the evolutionary constraints that prevent complete development of hermaphroditic primordia as such, thereby leading to the formation of unisexual male florets.

Phylogenetic analysis of $B d T s 2$ along with sequences of $T s 2$ and $T s$-like genes from 21 other monocot taxa and one dicot, Silene latifolia, obtained from the National Center for Biotechnology Information (NCBI), placed $B d T s 2$ with its close relatives (Bouteloua spp.) within the subfamily Chloridoideae. Among all these grass species, the role of $T s 2$ and its homolog as a sex-determining gene has only been shown in maize and eastern gamagrass, which belong to the subfamily Panicoideae. Our results potentially extend the role of a $T s 2$ homolog as a sex-determining gene into the Chloridoideae subfamily by associating the involvement of $B d T s 2$ in buffalograss staminate floret development.

In testing our hypothesis regarding the regulation of $B d T s 2$ activity by pistil smut, we found that $B d T s 2$ expression levels were substantially reduced (20-fold) in inflorescences of infected male plants compared with the same male genotypes not infected (Fig. 5). Moreover, expression levels of $B d T s 2$ in inflorescences of either infected male plants or infected female plants were lower than in noninfected female inflorescences. Thus, low expression levels of BdTs 2 in infected males, infected females, and noninfected females correspond to the presence of pistils, whereas high expression levels in nonin- 

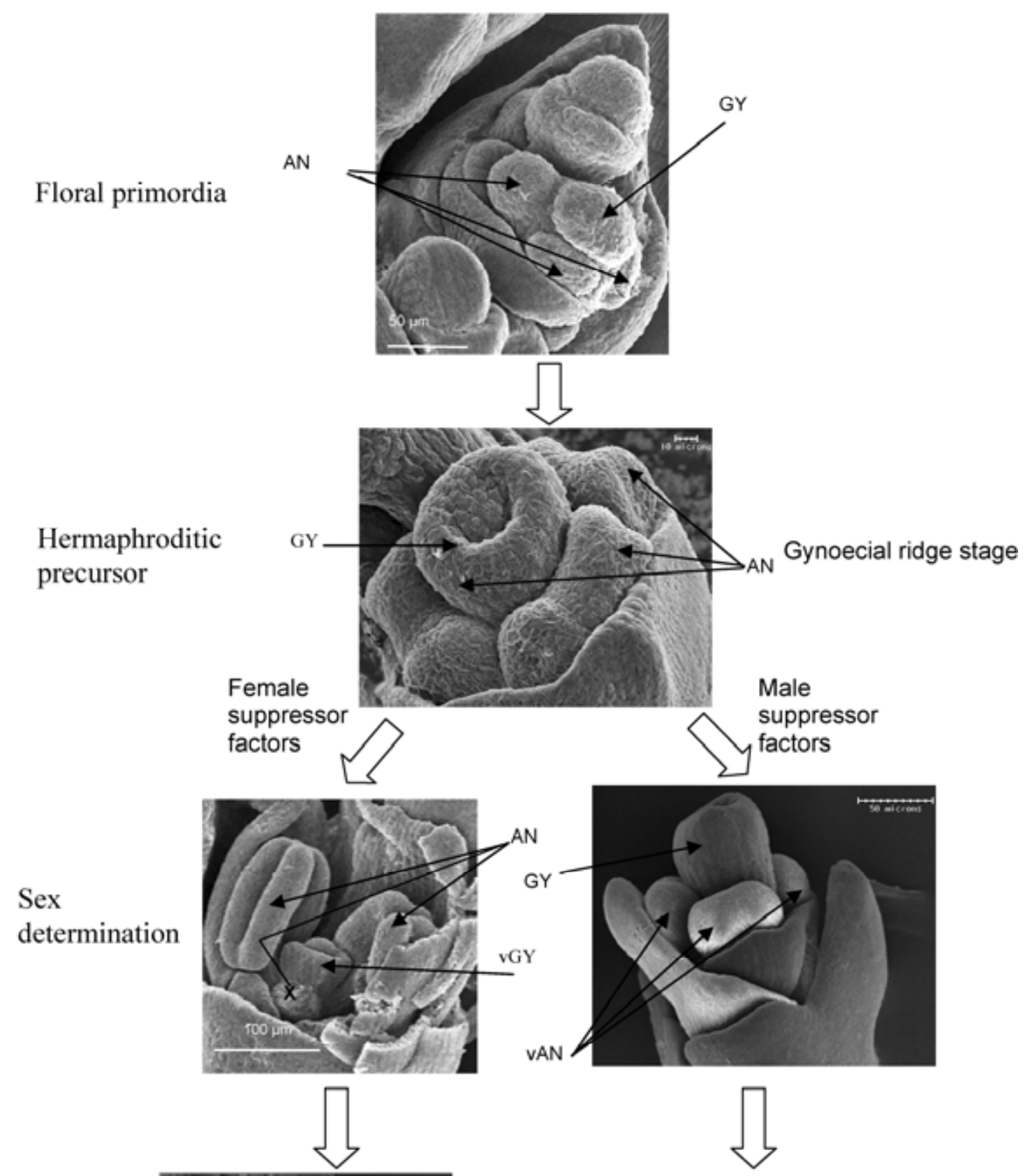

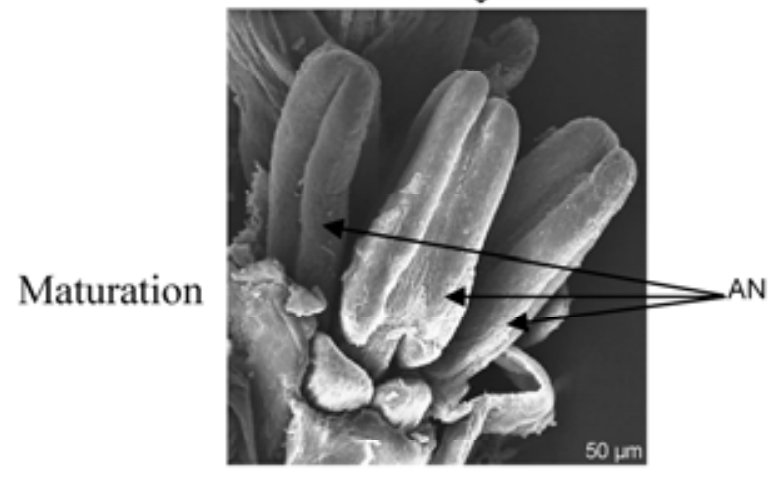

Male unisex floret

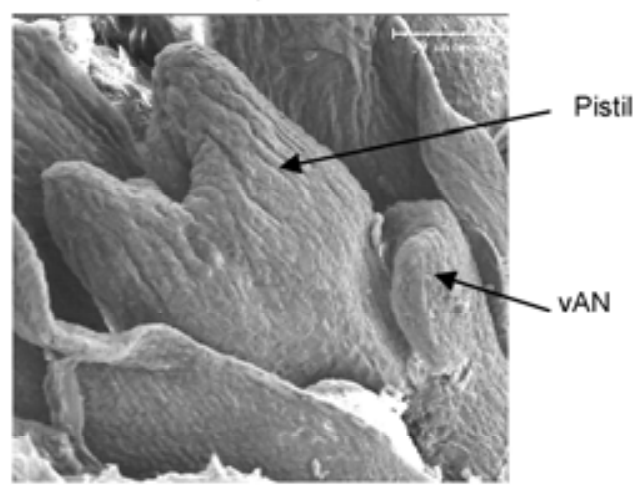

Female unisex floret

Fig. 3. Scanning electron micrographs depicting the developmental events of buffalograss unisexual floret formation. Florets initiate development as hermaphrodites containing both male (androecium [AN]) and female (gynoecium [GY]) organ primordia. At the gynoecial ridge stage, suppressor factors begin the transition of hermaphroditic precursor into unisexual florets. During sex determination, female-suppressor factors allow continued development of the androecium into a whorl of three stamens but leave behind a vestigial remnant of the gynoecium (vGY) (Note: one of the three stamens was removed [X] to make gynoecium visible). Male-suppressor factors allow continued development of gynoecium into a pistil but leave behind vestigial remnants of the androecium (vAN). As florets mature, they acquire an identity of either unisexual male or unisexual female. 
fected males correspond to the absence of pistils (Fig. 5). From these results, together with the loss-of-function mutations reported for ZmTs2 (Delong et al. 1993) and Gsf1 (Li et al. 1997), we conclude that pistil smut induces hermaphroditism in male buffalograss by either directly or indirectly downregulating the expression of $B d T s 2$.

\section{DISCUSSION}

Research describing the underlying molecular mechanisms of parasitically induced hermphroditism may provide additional insight into many interesting biological phenomenon, including host sex determination. Scutt and associates $(1997,2002)$ studied the molecular mechanism of anther smut-induced stamen development in female plants of dioecious $S$. latifolia and identified male-specific cDNAs, using subtractive suppression hybridization, and showed that these genes are inducible in females as a result of infection by the anther smut fungus. In doing so, the anther smut fungus provides a male sterility restoration factor during early stamen development in females. In another study, Kazama and associates (2009) identified and characterized a female-specific gene from S. latilfolia, SISUP,

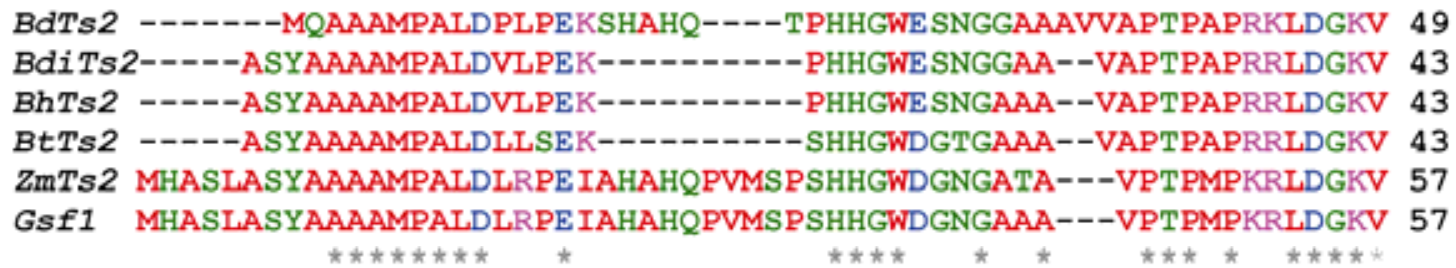

BdTs2 AIVTGGARGIGEAIVRLFAKHGARVVIADIDAAAGDALAAALGPQVSCVRCDVSVEDDVG 109 BdiTs2AIVTGGARGIGEAIVRLFVKHGARVVIADIDAAVGDALAAALGPQVSCVRCDVSVEDDVK 103 BhTs2 AIVTGGARGIGEAIVRLFARHGARVVIADVDAAAGDALAAALGPQVSCVRCDVSVEDDVR 103 BtTs2 AIVTEGARGIGEAIVRLFVKHGARVVIADIDDAAGDALAAALGPQVSCVRCDVSVEEDVK 103 ZmTs2 AIVTEGARGIGEAIVRLFAKHGARVVIADIDDAAGEALASALGPQVSFVRCDVSVEDDVR 117 Gsf1 AIVTEGARGIGEAIVRLFAKHGARVVIADIDDAAGEALAAALGPQVSFVRCDVSVEEDVR 117 ****

BdTs2 RAVEWAVARHG-RLDVLCNNAGVLGRQTRAAKSILSFDAAEFDAVLRVNALGAALGMKHA 168 BdiTs2RAVEWAVARHG-RLDVLCNNAGVLGRQTRAAKS ILSFDAGE FDRVLRVNALGAALGMKHA 162 BhTs2 RAVEWAVARHG-RLDVLCNNAGVLGRQTRAAKSILSFDAGE FDRVLRVNALGAALGMKHA 162 BtTs2 RAVEWAVARHG-RLDVLCNNAGVLGRQTRAAKSILSFDAGE FDRVLRVNALGTALGMKHA 162 ZmTs2 RAVDWALSRHGGRLDVYCNNAGVLGRQTRAARSILSFDAAEFDRVLRVNALGAALGMKHA 177 Gsf1 RAVDWALSRHGGRLDVYCNNAGVLGRQTRAAKSILSFDAGEFDRVLRVNALGAALGMKHA 177

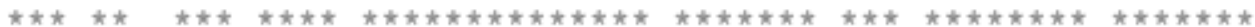

BdTs2 ALAMAPRRAGSIVSVSSVAGVLGGLGPHA TASKAAIVGLTKNAACELGAHGIRVNCVSP 228 BdiTs2ALAMAPRRAGSIVSVASVAGVLGGLGPHA TTASKHAIVGLTKNAACELGAHGIRVNCVSP 222 BhTs2 ARAMAPRRAGSIVSVASVAGVLGGLGPHA TTASKHAIVGLTKNAACELGAHGIRVNCVSP 222 BtTs2 ALAMAPRRAGSIVSVASVAGVLGGLGPHA PTASKHAIVGLTKNAACELGAHGIRVNCVSP 222 ZmTs2 ARAMAPRRAGSIVSVASVAAVLGGLGPHA PTASK HAIVGLTKNAACELRAHGVRVNCVSP 237 GSI1 ARAMAPRRAGSIVSVASVAGVLGGLGPHA YTASK HAIVGLTKNAACELGAHGVRVNCVSP 237

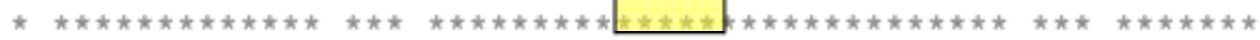

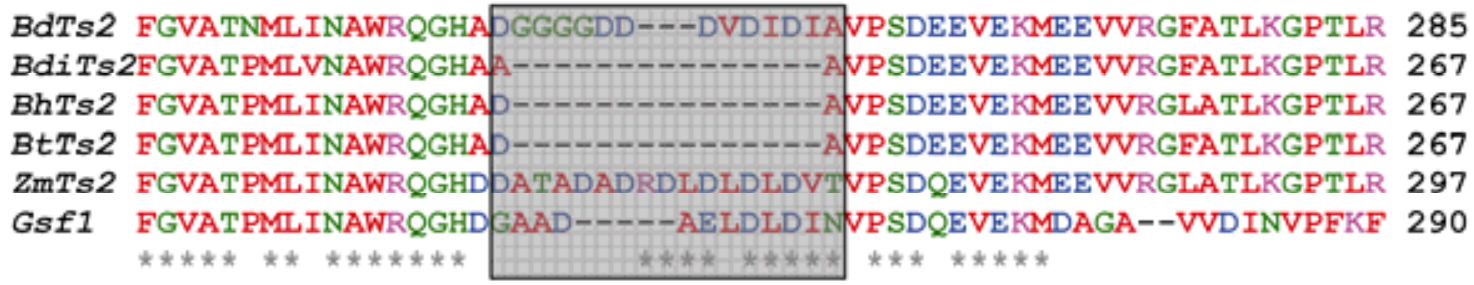

BdTs2 PRDIAEAVLFLASDESRYVSGHNLVVDGGVTTSRNLIGL 324

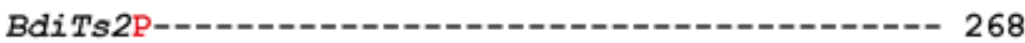

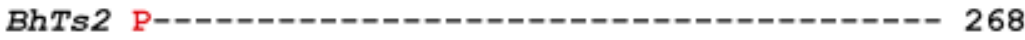

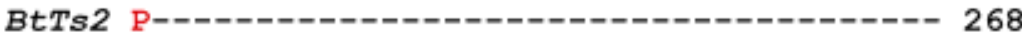

ZmTs2 PRDIAEAVLFLASDEARYISGHNLVVDGGVTTSRNLIGL 336

Gsf1 LFSFTDGRYIFGFSKANDQASHRMLDTFSKKKIMKFLII 329

Fig. 4. Multiple alignment of predicted amino acid sequences for Ts2 obtained from buffalograss (BdTs2, ABE65370), Bouteloua dimorpha (BdiTs2, AAR16175), B. hirsuta (BhTs2, AAR17511), B. trifida (BtTs2, AAR06288), maize (ZmTs2, AAC37345), and eastern gamagrass (Gsf1, AAB57738), using the Clustal W program. Asterisks (*) indicate sites with conserved amino acids. Yellow-shaded areas indicate GARGIG and YTASK amino acid motifs characteristic of the short-chain dehydrogenase reductase protein subfamily. Gray-shaded area indicates a hypervariable region present in maize, eastern gamagrass, and buffalograss.

244 / Molecular Plant-Microbe Interactions 
a homolog of the SUPERMAN gene from Arabidopsis. SISUP was shown to express in arrested stamen primordia until the ovary had fully matured. Desuppression of stamen development resulting from infection by the anther smut fungus in female flowers of $S$. latifolia was accompanied by a significant reduction in SISUP transcript levels, suggesting that SlSUP has a role in the suppression of stamen development in female flowers of S. latilfolia (Kazama et al. 2009). Our results show

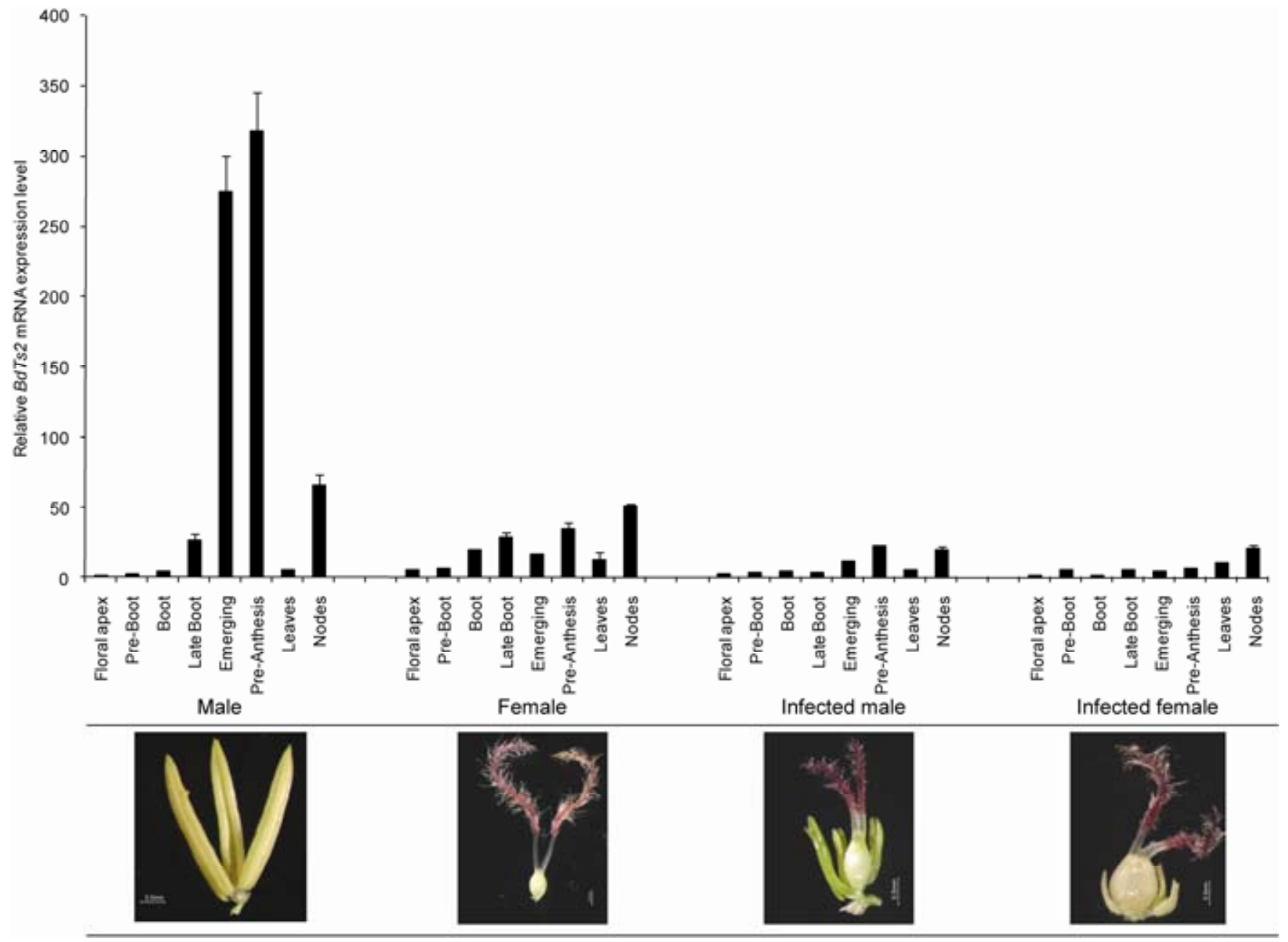

Fig. 5. Corollary evidence for the role of the female-suppressor gene $B d T s 2$ in buffalograss unisexual floret development and its regulation by pistil smut. Quantitative real time polymerase chain reaction analysis of relative BdTs2 expression levels for different stages of inflorescence development and for basal meristem leaves and vegetative meristems (nodes) in male and female sex forms infected or noninfected with pistil smut. Pictures of mature florets correspond to their respective sex forms of either noninfected or infected plants.
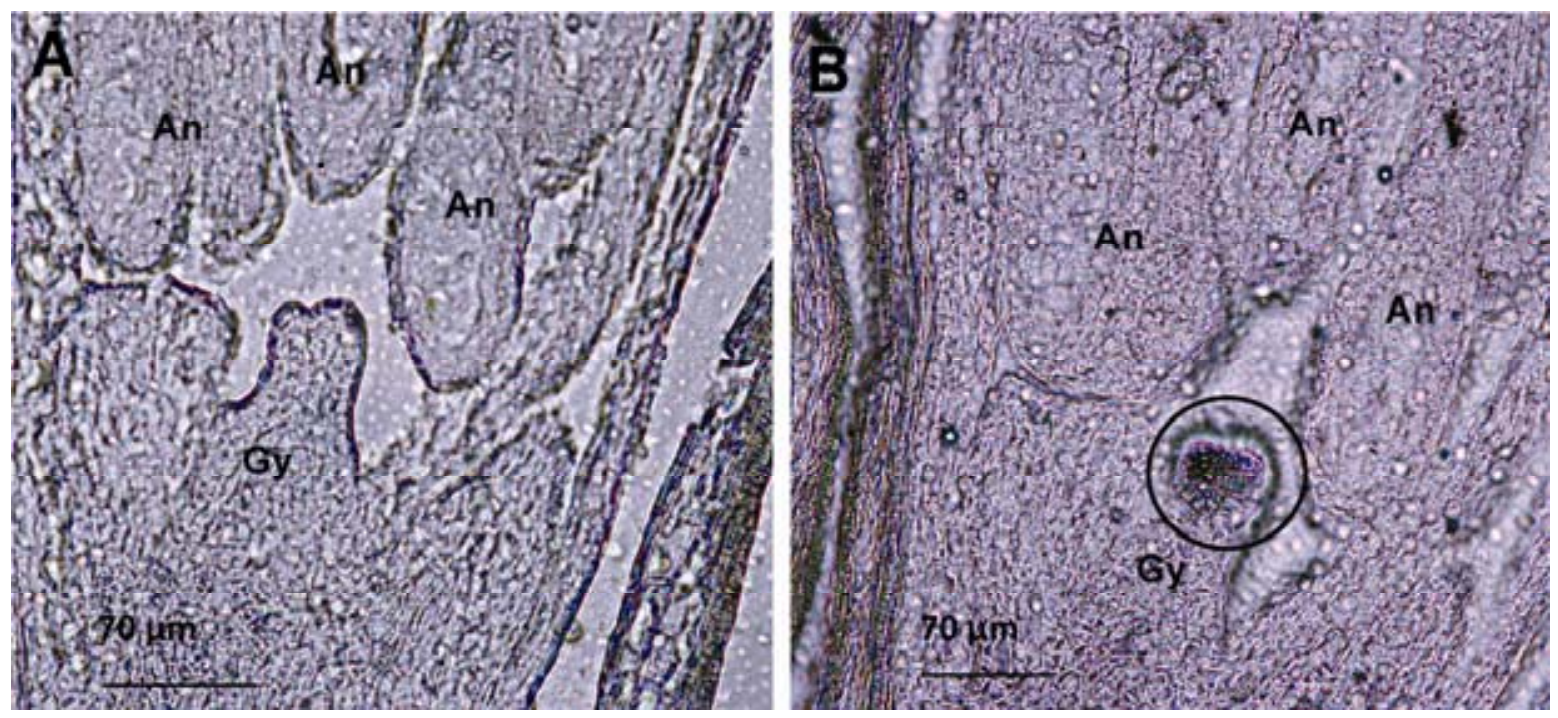

Fig. 6. RNA in situ hybridization of digoxyginin-labeled $B d T s 2$ probe in maturing male florets. A, Control sense probe, no hybridization. B, $B d T s 2$ probe hybridizes to subepidermal tissue of gynoecium (circled) at ridge stage of development in a unisexual male floret. An, anther; Gy, gynoecium. 
similar evidence describing the molecular mechanism underlying parasitically induced hermaphroditism in male buffalograss but for the opposite sex.

Our experimental hypothesis was that pistil smut-induced hermaphroditism of male buffalograss phenotypically mimics maize ts1/ts 2 and Tripsacum gsfl mutants. Wild-type maize $T s 2$ and Tripsacum Gsf1 phenotypes exhibit arrested female sex organ development in their respective male florets, presumably through cell-death programming (Calderon-Urrea 1999; Delong et al. 1993). Electron microscopy reveals a similar pattern of unisexual floret development in buffalograss as that described in maize (Cheng et al. 1983; Irish and Nelson 1993; Mitchell and Diggle 2005) and eastern gamagrass (Li et al. 1997). Expression studies of BdTs 2 during male buffalograss sex determination, using quantitative real-time PCR and in situ hybridization, demonstrate that $B d T s 2$ is spatially and developmentally comparable to expression patterns of the putative female suppressor genes ZmTs2 (Delong et al. 1993) and Gsfl (Li et al. 1997). Moreover, the spatial and temporal patterns of the high expression levels of BdTs 2 in noninfected male buffalograss corresponds to the absence of pistils, while low expression levels correspond to the presence of pistils in infected males and in noninfected and infected females. However, our quantitative real-time PCR results show that BdTs2 expression continued within the arrested gynoecium of noninfected male buffalograss florets until the male sex organs had matured compeletely. Similar results were shown in the $\mathrm{Si}$ lene-anther smut system, wherein the male suppression factor SISUP maintained expression in arrested stamen primordia until the female sex organs had matured completely in noninfected female plants (Kazama et al. 2009). Thus, perhaps the continuous expression of sex-determining genes that are capable of being regulated by parasites is a characteristic of coevolution underlying parasitically induced hermaphroditic systems. This is purely speculative but certainly warrants further study. Another explanation for the continued expression of $B d T_{s} 2$ within arrested gynoeciums is that buffalograss florets exhibit an asynchronous pattern of growth during the early stages of inflorescence development and that, as inflorescences mature, more and more florets synchronously reach a uniform stage of development. Given the continued expression of BdTs 2 within arrested gynoeciums throughout male sex organ maturity, the eventual synchronicity of floret development provides a potential explanation for the increased levels of $B d T s 2$ expression during later stages of inflorescence development.

$T s 2$ is known to have complicated expression patterns within maize florets ( $\mathrm{Wu}$ et al. 2007). $T s 2$ is believed to have served as a mediator of cell death in other developmental pathways prior to its acquiring its role as a female-suppressor gene (Kellogg 2000, 2001; Le Roux and Kellogg 1999). For example, in hermaphroditic rice and dioecious $S$. latilfolia, Ts2-like genes are not found to express in gyneociums but rather in other plant parts including anthers, lemma, palea, leaves, and roots (Malcomber and Kellogg 2006). In buffalograss, our quantitative real-time PCR results also show the expression of $B d T s 2$ in leaves and nodes from both male and female plants, indicating a role for $B d T s 2$ in additional developmental activities. However, unlike rice and $S$. latilfolia, our in situ hybridization results show the expression of $B d T s 2$ precisely in arrested gynoecium of staminate florets of buffalograss and not in other floral organs, indicating that the expression levels of $B d T s 2$ in male inflorescences is most likely due to its expression in the arrested gynoecium. Clearly, more research is needed to determine the regulatory role and the additional functions of $T s 2$.

Cloning and sequencing of the full-length cDNA region of $B d T s 2$ revealed that the amino acid sequence of $B d T s 2$ most closely aligns with $T s 2$ from related species belonging to the genus Bouteloua, supporting the inclusion of buffalograss into the Bouteloua genus (Columbus 1999). However, BdTs2 was found to contain a hypervariable region that is shared with $Z m T s 2$ and $G s f 1$ but is lacking in $T s 2$ sequences from other Bouteloua species. The hypervariable region observed within $B d T s 2, Z m T s 2$, and Gsf1 might merely represent the presence of variable simple sequence repeats. However, this hypervariable region does contain different combinations of direct and inverted repeats as well as palindrome nucleotide sequences (data not shown) and resides only $41 \mathrm{bp}$ from the Ac transposon insertion site described by Delong and associates (1993). Transposon excision is known to leave behind variable nucleotide patterns of transposable elements known as 'transposon footprints' (Scott et al. 2006). Therefore, an alternative explanation is that this hypervariable region might represent a regional hot spot for transposon activity. Nonetheless, the extent to which BdTs2 deviates from other Bouteloua amino acid sequences is perhaps not surprising, given the fact that the taxonomic treatment of the Bouteloua genus has long been controversial and was only recently expanded to include nine additional genera (Columbus 1999), including monotypic genus Buchlö̈ (Engelmann, 1859). Furthermore, Ts2 sequences among Bouteloua species appear polyphyletic, given the fact that sequences from B. trifida (AY426327) and B. hirsuta (AY434539) reside outside of the phylogenic cluster of Bouteloua species (Fig. 7).

The ability of pistil smut to manipulate buffalograss development has not been the subject of scientific study beyond that of the taxonomic classification of the parasite (Chandra and Huff 2008; Kellerman and Swingle 1889). In male buffalograss, pistil smut infection presumably prevents BdTs2-mediated cellular arrest of pistil development, allowing the unconstrained development of gynoeciums within florets that were otherwise destined to become staminate, thereby making them hermaphrodite. Whether $B d T s 2$ is downregulated directly from a product produced by the fungus itself or by the host buffalograss in response to infection is not known. The exact target of pistil smut infection during male sex determination in buffalograss may not directly be $B d T s 2$ but may lie upstream of the $B d T s 2$ biosynthetic and developmental pathway. In maize, both $t s 2$ and $t s 1$ mutations are required to eliminate pistil primordia in staminate florets (Calderon-Urrea and Dellaporta, 1999; Irish et al. 1994). Now that the nucleotide sequence and signaling pathway of $T s l$ has been elucidated (Acosta et al. 2009), the isolation and characterization of $T_{s} 1$ from buffalograss may provide additional insight regarding the regulatory role of pistil smut on buffalograss sex determination pathway. Acosta and associates (2009) discovered that application of jasmonic acid to developing maize inflorescences rescued mutant $t s 1$ and $t s 2$ phenotypes, revealing a role for jasmonic acid in unisexual flower development in maize. Some of our preliminary work has indicated higher levels of abscissic acid (ABA) in infected plants of buffalograss as compared with noninfected plants (unpublished data). ABA has been shown to play an antagonistic role in a plant's defense against biotrophic pathogens and to interact in the jasmonic-acid biosynthetic pathway (Bari and Jones 2009).

Within grasses, development of pistils in female florets and development of stamens in male florets are believed to be under separate genetic control as the developmental arrest of opposite sexes does not co-vary in evolutionary time (Malcomber and Kellogg 2006). Nonetheless, pistil smut has the ability to alter these separate genetic sex-determining mechanisms at the same time (Chandra and Huff 2008). We speculate that pistil smut infection is independently targeting both male- and femalesuppressor loci or is acting early in the developmental sequence 
by regulating meristem determinacy genes (Bortiri and Hake 2007) and, in turn, indirectly regulating downstream male and female sex-determining loci. We theorize that parasitically induced hermaphroditism is a product of a potential long-term and highly specialized coevolutionary process in which the parasite is able to remove the developmental constraints laid down during dioecy evolution of the host. In doing so, the fungus permits host expression of an ancestral hermaphroditic phenotype that existed back in time and is not the result of any permanent genetic change within the host, as would be the case for an atavism or a genetic reversion. We refer to such parasitically induced retrospective phenotypes as a 'retrophenotype.' These retrophenotypes raise interesting coevolutionary biology questions. For example, Wilson (1983) asked whether 'such patterns of parasitism happen by chance or have parasites (like pistil smut) played a role in the evolution of separate sexes in their hosts?'

The ability of pistil smut to induce the development of additional seed-bearing organs would seem to have potential agronomic utility (Jackson et al. 1992). Definitely more comprehensive research needs to be performed to address the more basic aspects of the buffalograss-pistil smut system in order to exploit the ability of pistil smut infection to regulate its host sex expression and meristem determinacy at the molecular and biochemical levels. $B d T s 2$ knock-out needs to be conducted in buffalograss to establish a direct relationship between BdTs2 loss-of-function mutation with the suppression of ovary development in male buffalograss. Investigation of buffalograss at the whole-genome level, such as through suppressive subtraction hybridization, will be informative in identification of additional genes and sex-specific transcripts regulated by pistil smut infection. Future work on the buffalograss-pistil smut system must also involve detailed hormone profiling of infected and noninfected plants to elucidate the possible mode of action of the fungus and the biochemistry of the interaction with its host.

\section{MATERIALS AND METHODS}

\section{Plant material.}

Seed of the Mexican-A diploid $(2 n=20)$ race of buffalograss (Huff et al. 1993) were germinated on moistened paper disks at $30^{\circ} \mathrm{C}$ in the dark. Seedlings were transplanted into greenhouse potting soil (Promix, Premier Horticulture, Inc., Quakertown , PA, U.S.A.), and after six weeks of growth, each individual genotype was vegetatively propagated into four replicate clones, two of which were infected with pistil smut by embedding teliospores into the soil surface close to the base of the plant and two of which were left noninfected. A total of 49 genotypes (21 female and 28 male, a total of 196 clones)

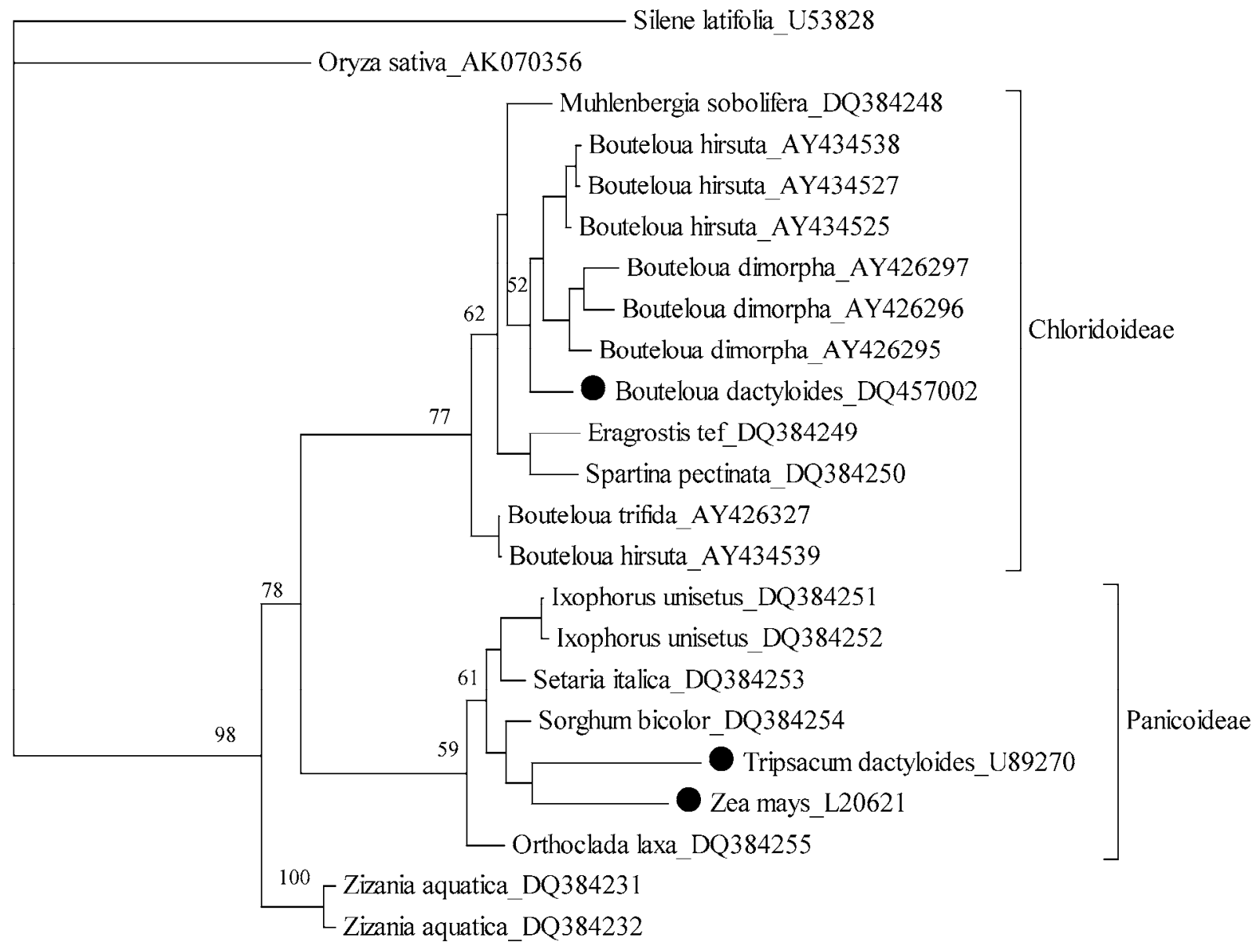

\section{0 substitutions/sequence}

Fig. 7. Phylogenetic relationship of BdTs2 DNA sequence (Bouteloua dactyloides) with 22 additional Tasselseed2 (Ts2) and Ts2-like short-chain dehydrogenase/reductase sequences. Numbers above branches indicate bootstrap support. This most parsimonious tree was generated from the maximum parsimony method using the general time reversible plus gamma distribution model. Black dots $(\bullet)$ represent taxa for which the role of $T s 2$ as a sexdetermining locus has been suggested (buffalograss, Bouteloua dactyloides; eastern gamagrass, Tripsacum dactyloides; maize, Zea mays). 
grown in the greenhouse $\left(80^{\circ} \mathrm{C}\right.$ day and $70^{\circ} \mathrm{C}$ night temperatures) under natural day-length conditions were examined to study the effects of pistil smut infection.

\section{Stages of buffalograss inflorescence development.}

We categorized buffalograss inflorescence development into six stages according to the following criteria: floral apex, represents the transition from vegetative meristem to flowering apex by a slight elongation of the flowering culm; preboot, when the ligule of the flag leaf becomes visible and the inflorescence begins to slightly enlarge within the flag leaf sheath; boot, when the sheath becomes noticeably swollen by enlargement of the inflorescence; late-boot, prior to emergence of inflorescence from sheath; emerging, first appearance of the inflorescence from within the sheath; and preanthesis, visible sign of first floret opening within an inflorescence. Buffalograss florets typically exhibit an asynchronous pattern of growth during the early stages of inflorescence development; however, as the inflorescence matures, more and more florets synchronously reach the anthesis stage of development.

\section{Scanning electron microscopy.}

Spikelets from noninfected and infected buffalograss of both sex forms from the six stages of inflorescence development were dissected to remove outer and inner glumes in order to expose the developing sex organs. Specimens were fixed in $2.8 \%$ gluteraldehyde and $0.02 \%$ Triton $\mathrm{X}$ in $0.1 \mathrm{M}$ HEPES $(N-$ 2-hydroxyethylpiperazine- $N$ '-2-ethanesulfonic acid) buffer, $\mathrm{pH}$ 7.2 , overnight at $4^{\circ} \mathrm{C}$. The specimens were then postfixed in $1 \%$ osmium tetraoxide for $2 \mathrm{~h}$, followed by dehydration in an alcohol series $(25,50,70,85,95$, and $100 \%$ ethanol for $5 \mathrm{~min}$ each) in preparation for critical point drying. After critical drying, the specimens were mounted onto aluminium stubs using conductive colloidal silver, followed by sputter coating (10 $\mathrm{nm}$ ) with gold particles in a vacuum. Secondary electron emission images of the prepared conductive specimens were taken using a JSM5400 scanning electron microscope with an accelerating voltage of $10 \mathrm{kv}$.

\section{Isolation of the full-length $T s 2$ homolog (BdTs2) from buffalograss and amino acid sequence analysis.}

Hotstart, touchdown PCR was performed on the genomic DNA extracted from noninfected buffalograss to amplify a 497-nt region of $T s 2$ to be used as a probe for gene expression studies. Amplification reaction mixture (per $25 \mu \mathrm{l}$ ) contained $1 \times$ buffer, $2 \mathrm{mM} \mathrm{MgCl} 2,0.25 \mathrm{mM}$ dNTPs, 5\% dimethyl sulfoxide, $1 \mathrm{M}$ betaine, $2.5 \mathrm{U} \mathrm{Taq}$ polymerase, and $1 \mu \mathrm{l}$ DNA template (extracted by standard CTAB [cetyltrimethylammonium bromide] procedure). Forward (5'CGCGCCGCCAAGA GCA TCCC 3 ') and reverse (5'CGCCGCCGTCC ACGACCA GGTTG3') primers were each included in the reaction mixture at a concentration of $0.15 \mu \mathrm{M}$. PCR cycling parameters were initial denaturation for $4 \mathrm{~min}$ at $95^{\circ} \mathrm{C}$ followed by 16 cycles of $1 \mathrm{~min}$ at $94^{\circ} \mathrm{C}, 1 \mathrm{~min}$ at $65^{\circ} \mathrm{C}$ (reducing temperature $1^{\circ} \mathrm{C}$ per two cycles), $1 \mathrm{~min}$ at $72^{\circ} \mathrm{C}$ followed by 19 cycles of $1 \mathrm{~min}$ at $94^{\circ} \mathrm{C}, 1 \mathrm{~min}$ at $57^{\circ} \mathrm{C}, 1 \mathrm{~min}$ at $72^{\circ} \mathrm{C}$, with a final extension for $4 \mathrm{~min}$ at $72^{\circ} \mathrm{C}$. The resulting amplicon was gel-purified using QIAquick gel extraction kit (Qiagen Science, Inc., Germantown, MD, U.S.A.) and was cloned in pCRII-TOPO (Invitrogen, Carlsbad, CA, U.S.A.).

RACE ( $3^{\prime}$ and $\left.5^{\prime}\right)$ was performed on cDNA extracted from noninfected male buffalograss inflorescence in order to isolate the full-length $B d T s 2$ including $3^{\prime}$ and 5' untranslated regions. First-strand cDNA synthesis and $3^{\prime}$ and $5^{\prime}$ RACE, based on nested PCR, using adapter primers and $B d T_{s} 2$-specific primers, were carried out according to the guidelines of BD SMART RACE cDNA amplification kit (BD Clontech, Mountain View,
CA, U.S.A.). In order to sequence the full-length coding region of $T s 2(1,226 \mathrm{nt})$, we designed forward (5'CGGCCCCCAAT AG ATACAT3') and reverse (5'TCACAAGCC GATGAGGTT TC $3^{\prime}$ ) primers in the $5^{\prime}$ and $3^{\prime}$ regions of $B d T s 2$, respectively. Similar PCR conditions as above were used to amplify fulllength $B d T s 2$, which was then cloned in pCRII-TOPO (Invitrogen). Cloned full-length $B d T s 2$ was sequenced with the ABI Hitachi 3730XL DNA analyzer (Applied Biosystems, Foster City, CA, U.S.A.).

The NCBI national public database was used to extract amino acid sequence for $T s 2$ from maize (AAC37345) and $T s 2$ homologs from eastern gamagrass (AAB57738), buffalograss (ABE65370), Bouteloua dimorpha (AAR16175), B. hirsuta (AAR17511), and B. trifida (AAR06288). Multiple alignment of amino acid sequences was conducted with the CLUSTALW program using default alignment parameters.

\section{Quantitative real-time PCR.}

Total RNA from specific stages of developing inflorescences was extracted using the RNAqueous-4 PCR kit (Ambion, Austin, TX, U.S.A.). Two replicate RNA samples, pooled over genotypes, were extracted from each factor combination of sex form and infection treatment for each developmental stage of inflorescences. The internal oligonucleotide probe (5'CGCAG AGGCCGTGCT CTTCCTG3') was labeled with florescent dye 6-FAM at the 5' end and with quencher dye BHQ-1 at the $3^{\prime}$ end (Biosearch Technologies Inc., Richmond, CA, U.S.A.). The BdTs 2 amplicon upstream PCR primer corresponded to base 399 to 417 (5'CGCTCAGGCCCAGGGACA3') and the downstream PCR primer corresponded to base 457 to 478 (5' A TACATCTC CGGCCACAACCT 3'). 18S ribosomal (r)RNA served as an endogenous control and was amplified along with the target $B d T s 2$ amplicon to standardize the amount of sample RNA added to each reaction. PCR cycling parameters were $50^{\circ} \mathrm{C}$ for $3 \mathrm{~min}, 95^{\circ} \mathrm{C}$ for $10 \mathrm{~min}$, and then, 45 cycles of $95^{\circ} \mathrm{C}$ for $15 \mathrm{~s}$ and $60^{\circ} \mathrm{C}$ for $1 \mathrm{~min}$. Real-time detection of fluorescence emissions was performed on an ABI PRISM 7700 (Applied Biosystems, Bedford, MA, U.S.A.). Each replicate RNA sample was measured three times. Data acquisition and analysis were carried out using Sequence detection software (Applied Biosystems). Fold differences in the amount of target RNA were obtained through normalization to 18s rRNA expression levels.

\section{RNA in situ hybridization.}

Developing inflorescences from noninfected male plants were fixed in ice-cold fixative $(4 \%$ [wt/vol] paraformaldehyde; $4 \%$ [vol/vol] Triton- $\mathrm{X}$ in $1 \times$ phosphate buffered saline) under vacuum and were then incubated for $12 \mathrm{~h}$ at $4^{\circ} \mathrm{C}$ with gentle shaking, followed by dehydration in an ethanol series $(30,40$, $50,60,70,85$, and 95\%, 60 min each). Ethanol was removed and replaced with a series of ethanol and histoclear mixture followed by paraffin wax (Oxford Labware, St. Louis) infiltration at $60^{\circ} \mathrm{C}$. Inflorescences were sectioned, $8 \mu \mathrm{m}$ thick, with a Finnese microtome and were mounted on Probe-On plus slides (Fisher Biotech, Pittsburgh). Digoxigenin-labeled antisense RNA probe (497 nt) was prepared by in vitro transcription of $B d T s 2$ using T7 polymerase, and RNA in situ hybridization was performed following Jackson and associates (1994).

\section{Phylogenetic analysis.}

The nucleotide sequence of $T s 2$ from maize and its homologs from 21 other monocot taxa and one dicot, S. latifolia, were obtained from NCBI. Multiple alignment was conducted with the CLUSTALW program of MEGA version 3.1 (Kumar et al. 2004), using default alignment parameters. The nucleotide sequences were aligned for 1,394 positions, of which 380 
were conserved, 853 were variable, with 536 singleton sites, and 304 parsimony-informative sites. The transition/transversion ratio was 0.49 with 36 transitional pairs and 73 transversional pairs.

Modeltest 3.7 (Posada and Crandall 1998) with the Akaike information criterion was used to estimate the optimal model of evolution for conducting phylogenetic analyses and also for determining the parameters for likelihood assumptions. The general time reversible (GTR) model with a gamma shape parameter (referred to as GTR+G) fit the data set the best. The estimated base composition frequencies were: A, 0.2022; C, 0.3079 ; G, 0.3040; T, 0.1858; the gamma shape parameter was 0.4677 , and the substitution rate matrix was A to C, 1.4356; A to $\mathrm{G}, 2.5363$; A to $\mathrm{T}, 1.9689$; $\mathrm{C}$ to $\mathrm{G}, 2.7959$; $\mathrm{C}$ to $\mathrm{T}, 2.5363$; and $\mathrm{G}$ to $\mathrm{T}, 1.0000$. The estimated optimal model of evolution was utilized to construct a phylogenetic tree, maximum parsimony (MP) by PAUP 4.01b (Swofford 2002). Mega 3.1 was used to view and label trees generated from PAUP 4.01b. The MP tree was inferred using the heuristic search option with the random addition of trees and the branch swapping (tree bisection-reconnection) options of PAUP 4.10b. For MP analysis, 10,000 replications were run with automatically increasing the Maxtree (maximum numbers of trees stored) by 100. To evaluate branch robustness in the MP tree, bootstrap (Felsenstein 1985) analyses were conducted. Bootstrap support was estimated using 1,000 bootstrap replicates, each replicate consisting of 10 heuristic searches and random addition sequences, with no branch swapping and the multree option off.

\section{ACKNOWLEDGMENTS}

We gratefully acknowledge E. Kellogg and S. Malcomber for providing Ts2 PCR amplification conditions, P. McSteen for help in RNA in situ experiments, D. Charlesworth for reviewing our manuscript, and D. Lisch and D. Cosgrove for helpful discussions.

\section{LITERATURE CITED}

Acosta, I. F., Laparra, H., Romero, S. P., Schmelz, E., Hamberg, M., Mottinger, J. P., Moreno, M. A., and Dellaporta S. L. 2009. tasselseed1 is a lipoxygenase affecting jasmonic acid signaling in sex determination of maize. Science 323:262-265.

Ageez, A., Kazama, Y., Sugiyama, R., and Kawano, S. 2005. Male-fertility genes expressed in male flower buds of Silene latifolia include homologs of anther-specific genes. Genes Genet. Syst. 80:403-413.

Alexander, H. M., and Antonovics, J. 1988. Disease spread and population dynamics of anther-smut infection of Silene alba caused by the fungus Ustilago violacea. J. Ecol. 76:91-104.

Altizer, S. M., Thrall, P. H., and Antonovics, J. 1997. Vector behavior and the transmission of anther-smut infection in Silene alba. Am. Midl. Nat. 139:147-163

Antonovics, J., Hood, M., and Partain, J. 2002. The ecology and genetics of a host shift: Microbotryum as a model system. Am. Nat. 160:S40S53

Bari, R., and Jones, J.D.G. 2009. Role of plant hormones in plant defence responses. Plant Mol. Biol. 69:473-488.

Barrett, S. C. H. 2002. The evolution of plant sexual diversity. Nature 3:274-284.

Bortiri, E., and Hake, S. 2007. Flowering and determinacy in maize. J. Exp. Bot. 58:909-916.

Calderon-Urrea, A., and Dellaporta, S. L. 1999. Cell death and cell protection genes determine the fate of pistils in maize. Development 126:435441.

Chandra, A., and Huff, D.R. 2008. Salmacisia, a new genus of Tilletiales: Reclassification of Tilletia buchloëana causing induced hermaproditism in buffalograss. Mycologia 100:81-93.

Charlesworth, D. 2002. Androdioecy and the evolution of dioecy. Heredity 88:94-101.

Charlesworth, B., and Charlesworth, D. 1978. A model for the evolution of dioecy and gynodioecy. Am. Nat. 112:975-997.

Cheng, P. C., Greyson, R. I., and Walden, D. B. 1983. Organ initiation and the development of unisexual flowers in the tassel and ear of Zea mays. Am. J. Bot. 70:450-462.
Clay, K. 1991. Parasitic castration of plants by fungi. Trends Ecol. Evol. 6:162-166.

Columbus, J. T. 1999. An expanded circumscription of Bouteloua (Gramineae: Chloridoideae): New combinations and names. Aliso 18:61-65.

Delong, A., Calderon-Urrea, A., and Dellaporta, S. L. 1993. Sex determination gene TASSELSEED2 of maize encodes a short-chain alcohol dehydrogenase required for stage-specific floral organ abortion. Cell 74:757-768.

Duran, R., and Fischer, G.W. 1961. The genus Tilletia. Washington State University Press. Pullman, WA, U.S.A.

Engelmann, G. 1859. Two new dioecious grasses of the United States. Trans. St. Louis Acad. Sci.1:431-443.

Felsenstein, J. 1985. Confidence limits on phylogenies: An approach using the bootstrap. Evolution 39:783-791.

Fischer, G. W., and Holton, C. S. 1957. Biology and Control of the Smut Fungi. Ronald Press, New York.

Hood, M. E., and Antonovics, J. 2003. Plant species descriptions show signs of disease. Proc. Royal Soc. London Series B (Suppl.). 270:S156S158

Huff, D. R., and Wu, L. 1987. Sex expression in buffalograss under different environments. Crop Sci. 27:623-626.

Huff, D. R., and Wu, L. 1992. Distribution and inheritance of inconstant sex forms in natural populations of dioecious buffalograss (Buchloë dactyloides). Am. J. Bot. 79:207-215.

Huff, D. R., Peakall, R., and Smouse, P. E. 1993. RAPD variation within and among natural populations of outcrossing buffalograss. Theor. Appl. Genet. 86:927-934.

Irish, E. E., and Nelson, T. M. 1993. Development of TASSELSEED2 inflorescence in maize. Am. J. Bot. 80:292-299.

Irish, E. E., Langdale, J. A., and Nelson, T. M. 1994. Interaction between tasselseed genes and other sex determining genes in maize. Devel Genet. 15:155-171.

Jackson, D., Veit, B., and Hake, S. 1994. Expression of maize KNOTTED1 related homeobox genes in the shoot apical meristem predicts patterns of morphogenesis in the vegetative shoot. Development 120:405-413.

Jackson, L.L., Dewald, C. L., and Bohlen, C. C. 1992. A macromutation in Tripsacum dactyloides (Poaceae): Consequences for seed size, germination, and seedling establishment. Am. J. Bot. 79:1031-1038.

Jenkins, T. H., Jinhong, L., Scutt, C. P., and Gilmartin, P. M. 2005. Analysis of members of the Silene latifolia Cys2/His2 zinc-finger transcription factor family during dioecious flower development and in a novel stamen defective mutant ssfl. Planta. 220:559-571.

Kazama, Y., Fujiwara, M. T., Koizumi, A., Nishihara, K., Nishiyama, R., Kifune, E., Tomoko Abe, T., and Kawano, S. 2009. A SUPERMAN-like gene is exclusively expressed in female flowers of the dioecious plant Silene latifolia. Plant Cell Physiol. 50:1127-1141.

Kellerman, W. A., and Swingle, W. T. 1889. New species of Kansas fungi. J. Mycol. 5:11-14.

Kellogg, E. A. 2000. The grasses: A case study in macroevolution. Annu. Rev. Ecol. Syst. 31:217-238.

Kellogg, E. A. 2001. Evolutionary history of the grasses. Plant Physiol. 125:1198-1205

Kinney, M. S., Columbus, J. T., and Friar, E. A. 2003. Molecular evolution of the maize sex-determining gene TASSELSEED 2 in Bouteloud (Poaceae). Mol. Phyl. Evol. 29: 519-528.

Kumar, S., Tamura, K., and Nei, M. 2004. MEGA3: Integrated software for Molecular Evolutionary Genetics Analysis and sequence alignment. Brief. Bioinform. 5:150-163.

Le Roux, L. G., and Kellogg, E. A. 1999. Floral development and the formation of unisexual spikelets in the Andropogoneae (Poaceae). Am. J. Bot. 86:354-368.

Li, D., Blakey, C. A., Dewald, C. and Dellaporta, S. L., 1997. Evidence for a common sex determination mechanism for pistil abortion in maize and in its wild relative Tripsacum. Proc. Natl. Acad. Sci. U.S.A. 94:4217-4222.

Malcomber, S. T., and Kellogg, E. A. 2006. Evolution of unisexual flowers in grasses (Poaceae) and the putative sex-determining gene, TASSELSEED2 (TS2). New Phytol. 170:885-899.

Mitchell, C. H., and Diggle, P. K. 2005. The evolution of unisexual flower: Morphological and functional convergence results from diverse developmental transition. Am. J. Bot. 92:1068-1076.

Posada, D., and Crandall, K. A. 1998. Modeltest: testing the model of DNA substitution. Bioinformatics 14:817-818.

Sampson, K. 1933. The systemic infection of grasses by Epichloë typhina (Pers.). Trans. Brit. Mycol. Soc. 18:30-47.

Sánchez-Ken, J. G., Clark, L. G., Kellogg, E. A., and Kay, E. E. 2007. Reinstatement and Emendation of Subfamily Micrairoideae (Poaceae). Syst. Bot. 32:71-80.

Scott, L., LaFoe, D., and Weil, C. F. 2006. Adjacent sequences influence 
DNA repair accompanying transposon excision in maize. Genetics 142:237-246.

Scutt, C. P., Li, Y., Robertson, S. E., Willis, M. E., and Gilmartin, P. M 1997. Sex determination in dioecious Silene latifolia: Effects of the Y chromosome and the parasitic smut fungus (Ustilago violacea) on gene expression during flower development. Plant Physiol. 114:969-979.

Swofford, D. L. 2002. PAUP: Phylogenetic Analysis Using Parsimony. Version 4. Sinauer Associates, Sunderland, MA, U.S.A.

Uchida, W., Matsunaga, S., Sugiyama, R., Kazama, Y., and Kawano, S. 2003. Morphological development of anthers induced by the dimorphic smut fungus Microbotryum violaceum in female flowers of the dioecious plant Silene latifolia. Planta 218:240-248.

Westergaard, M. 1958. The mechanism of sex determination in dioecious flowering plants. Adv. Genet. 9:217-281.

Wilson, M. F. 1983. Plant Reproductive Ecology. John Wiley \& Sons,
New York.

Wu, X., Knapp, S., Stamp, A., Stammers, D. K., Jörnvall, H., Dellaporta, S. L., and Oppermann, U. 2007. Biochemical characterization of TASSELSEED 2, an essential plant short-chain dehydrogenase/reductase with broad spectrum activities. FEBS J. 274:1172-1182.

Ye, D., Oliveira, M., and Veuskens, J. 1991. Sex determination in the dioecious Melandrium. The X/Y chromosome system allows complementary cloning strategies Plant Sci. 80:93-106.

Young, H. J. 2002. Diurnal and nocturnal pollination of Silene alba (Caryophyllaceae). Am. J. Bot. 89:433-440.

\section{AUTHOR-RECOMMENDED INTERNET RESOURCE}

NCBI website: www.ncbi.nih.gov 